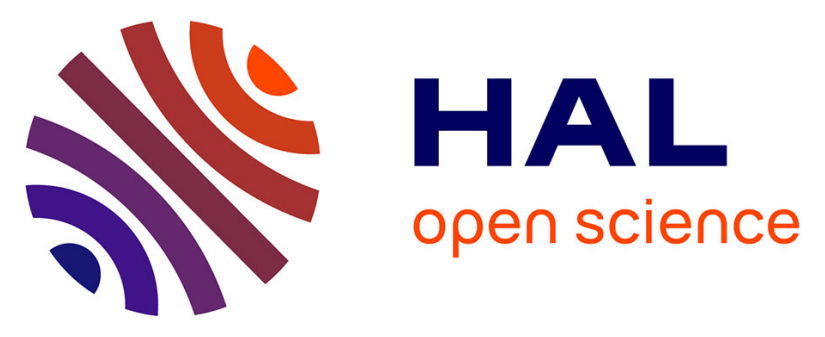

\title{
In-situ characterization of layered pollution in the wintertime Arctic atmosphere by small sensors
}

Tjarda J Roberts, Meeta Cesler-Maloney, William Simpson, Jingqui Mao, Brice Barret, Slimane Bekki, Brice Temine-Roussel, Barbara d'Anna, Julia Maillard, François Ravetta, et al.

\section{To cite this version:}

Tjarda J Roberts, Meeta Cesler-Maloney, William Simpson, Jingqui Mao, Brice Barret, et al.. In-situ characterization of layered pollution in the wintertime Arctic atmosphere by small sensors. EGU General Assembly 2021, Apr 2021, Online Meeting, Germany. pp.EGU21-15351, 10.5194/egusphereegu21-15351 . insu-03194356

\section{HAL Id: insu-03194356 \\ https://hal-insu.archives-ouvertes.fr/insu-03194356}

Submitted on 6 Feb 2022

HAL is a multi-disciplinary open access archive for the deposit and dissemination of scientific research documents, whether they are published or not. The documents may come from teaching and research institutions in France or abroad, or from public or private research centers.
L'archive ouverte pluridisciplinaire HAL, est destinée au dépôt et à la diffusion de documents scientifiques de niveau recherche, publiés ou non, émanant des établissements d'enseignement et de recherche français ou étrangers, des laboratoires publics ou privés.

\section{(c)(1)}

Distributed under a Creative Commons Attribution| 4.0 International License 
EGU21-15351

https://doi.org/10.5194/egusphere-egu21-15351

EGU General Assembly 2021

(c) Author(s) 2022. This work is distributed under

the Creative Commons Attribution 4.0 License.

\section{In-situ characterization of layered pollution in the wintertime Arctic atmosphere by small sensors}

Tjarda Roberts ${ }^{1}$, Meeta Cesler-Maloney ${ }^{2}$, William Simpson ${ }^{2}$, Jingqui Mao $^{2}$, Brice Barret ${ }^{3}$, Slimane Bekki $^{4}$, Brice Temine-Roussel ${ }^{5}$, Barbara d'Anna ${ }^{5}$, Julia Maillard ${ }^{4}$, Francois Ravetta ${ }^{4}$, Jean-Christophe Raut ${ }^{4}$, Andy Woods ${ }^{6}$, Eleftherios loannidis ${ }^{4}$, and Kathy Law ${ }^{4}$

1'LPC2E-CNRS, Laboratory of Physics and Chemistry of Space and the Environment, Orléans, France (Tjarda.Roberts@cnrs-

orleans.fr)

${ }^{2}$ Department of Chemistry, University of Alaska, Fairbanks, USA

${ }^{3}$ LA-CNRS, Laboratoire d'Aerologie, Toulouse, France

${ }^{4}$ LATMOS-CNRS, Laboratoire Atmosphères, Observations Spatiales, Paris, France

${ }^{5}$ LCE-CNRS, Laboratoire Chimie Environnement, Aix-Marseille University, France

${ }^{6} \mathrm{BPI} \&$ Department of Earth Sciences, University of Cambridge, UK

During the Arctic winter, local emissions (e.g. from home-heating, traffic, power station or industry plumes) coupled to poor dispersion caused by strong temperature inversions can lead to severe air pollution events. For example, each winter, Fairbanks (Alaska) experiences high abundances of gaseous pollutants and particulate matter (PM), leading to air-quality exceedances. However, there is still limited knowledge on the coupled physico-chemical and dynamical processes that cause wintertime Arctic pollution and aerosol formation under the very cold and low light conditions, and where levels of oxidants such as ozone at the surface can become depleted under limited vertical mixing. Here, we demonstrate novel deployment of low cost small sensors measuring $\mathrm{PM} 2.5$, gases $(\mathrm{CO}, \mathrm{NO}, \mathrm{NO} 2, \mathrm{O} 3)$ and meteorological parameters $(\mathrm{P}, \mathrm{T}, \mathrm{RH})$ to characterize Arctic atmospheric composition and properties, including mapping vertical distributions.

Our three-week pre-ALPACA (Alaskan Layered Pollution and Chemical Analysis) intensive fieldcampaign took place in downtown Fairbanks in Nov-Dec 2019. Small sensor temperaturedependencies were characterized by instrument cross-comparisons and correction-algorithms developed. Sensors were then deployed near-ground, on the roof of a $19 \mathrm{~m}$ building, and on a vertical pulley system set-up along the side of the building for vertical profiling. The small sensors show a strong capability to capture temporal variations in PM2.5, $\mathrm{CO}, \mathrm{NO}$ and $\mathrm{NO}_{2}$ and $\mathrm{O}_{3}$, across a wide temperature range: surface gas and particle abundances became elevated during a coldpolluted period (temperatures as low as $-30 \mathrm{C}$ ) and again became elevated during a subsequent warm-polluted period (temperatures around $-3 \mathrm{C}$ ). Vertical profiling during the warm-polluted period identified strong temperature inversions associated with near-surface layers of high PM2.5 and $\mathrm{CO}$ that are distinct from an overlying clean, warm, humid air-mass. During the cold-polluted period, temperature inversions were present but less strong, there was little vertical structure in composition, and PM2.5 was often greater at $20 \mathrm{~m}$ than at the surface. This finding contrasts with a 
full winter-season analysis that shows cold surface temperatures typically associated with strong inversions and PM highest at the surface. We invoke plume-rise modelling to show how buoyant plumes from local emissions (e.g. home-heating) can reach heights of about 10-20 m, allowing polluted emissions to rise and accumulate at altitude unless inversions are sufficiently strong to constrain the plume-rise. Causes of the temperature inversions include radiative cooling and advection of overlying warm-air. Our study highlights how small sensor measurements and vertical profiling can help elucidate the coupled processes of atmospheric chemistry, physics, dynamics and emissions that lead to surface air pollution episodes at high latitudes.

This study forms part of the Alaskan Layered Pollution and Chemical Analysis (ALPACA) project https://alpaca.community.uaf.edu/. We are grateful for technical support from Alaska-DEC, LPC2E, UAF, SEOSS, Alphasense and SouthCoastScience. 